\title{
1245 occurrences of donc in the speech of Chinese L1 speakers of French in France
}

\author{
Delin Deng ${ }^{1 *}$ \\ ${ }^{1}$ EHESS, 54 boulevard Raspail, 75006, Paris, France
}

\begin{abstract}
It seems that the French native speakers do not always use donc as argumentative connectors in oral French. In fact, its use as discourse markers has been addressed by many researchers in linguistics. To avoid the overlaps between different categories of functions established by other scholars, we propose to distinguish only two types of donc: the argumentative donc and the discursive donc. This paper exploited the discursive use of the French particle donc in the oral production of Chinese L1 speakers of French in France. We found that donc could have the exemplification function in non-native speech, which was not reported in native speakers' speech. Meanwhile, from the sociolinguistic perspective, we also investigated how some social factors influence its use in nonnative speakers' speech. Among different extralinguistic factors examined in this article, only the extracurricular contact with native speakers of French was proved to be statistically significant.
\end{abstract}

\section{Introduction}

It is assumed that donc originates in Latin dum, either through the elaboration dumque, or through dunc, a late Latin form which is believed to be the result of analogy with the pair tum/tunc. (von Wartburg, 1928; Ernout \& Meillet, 1951; Bloch and von Wartburg, 1968). Several uses of donc in old French were outlined by Hansen (1997). Firstly, it has a temporal use. Secondly, it could introduce the apodosis in hypothetical constructions. Thirdly, donc could introduce, in Modern French, results and conclusions. Fourthly, it could be used as as emphatic particles with imperatives. However, the temporal use is said to be the original one (Gamillscheg, 1957). Its evolution to the Modern French may be considered as a semantic shift, in which case, the particle lost its original meaning and extended to some new meanings. (Holm, 1988)

Donc has attracted the attention of many researchers in the recent decades. Its discursive functions have been widely documented in native speaker's speech. (see for example, Zenone, 1981; Hansen, 1997; Vlemings, 2003; Bolly \& Degand, 2009, etc.) However, to our knowledge, its use as discourse marker has seldomly been reported in non-native speech. As members of the target language community, non-native speakers could by all means acquire donc both in its standard use which is the argumentative use and its relatively new non-standard function as discourse markers through their daily contact with

* Corresponding author: delin.deng@gmail.com 
the native speakers of French, despite the fact that the discourse marker use is not taught explicitly in language classrooms.

Therefore, in this article I would like to, on one hand, exploit the discursive functions of donc in non-native speech to see if the non-native speakers also use donc as discourse markers besides its standard argumentative use. On the other hand, as social factors have been proved to be significant to the acquisition of some non-standard forms in both native and non-native speeches (see for example, Sankoff et al. ,1997; Rehner \& Mougeon, 1999; Rehner et al., 2003; Deng, 2017, etc.), I will also examine how social factors such as age, sex, extracurricular contact, etc. affect its use.

In this article, the discursive use of donc in native speech will be reviewed in the first place. Secondly, the methodology concerning the corpus, the participants as well as the social factors to be examined in the present work will be presented in detail. Thirdly, the results including the general tendency, the distribution of its functions in non-native speech as well as the impact of the extralinguistic factors will be discussed. Lastly, the conclusion on the current work and reflection on its future pedagogical implementations will be addressed.

\section{Discursive functions of donc in native speech}

After a first data cleaning of our corpus, we found a large number of donc in our non-native speakers' oral production. Chanet (2004) has established a list of 85 most frequent discourse markers used by native speakers of French in France. According to her list, donc is the second most used discourse marker with a frequency of 1 occurrence every 55 seconds. Before giving any further analysis of our data, we will first review its use in native speech. In fact, many researchers have tried to identify the various discursive functions of donc in oral French. We will start our presentation by Zénone's classification in 1981 and end with Delgar-Farrés' work in 2016.

\subsection{Zénone}

Zénone (1981) identified five discursive functions of donc:

1. Marking the resumption of something mentioned earlier:

Ex 1 : Donc, pour revenir à ce disait la dame précédemment, il est difficile d'envisager une solution à brève échéance (Zénone, 1981)

2. Discursive use :

Ex 2 : Que ta maison est donc jolie! (Zénone, 1981)

3. Argumentative use :

Ex 3 : B ne l'a pas lu donc il ne peut rien dire (Zénone, 1981)

4. Metadiscursive use :

Ex 4 : C'est votre point de vue donc que vous êtes en train d'énoncer? (Zénone, 1981)

5 Recapitulative use :

Ex 5: Tout individu humain a donc une dignité naturelle que le stoïcisme a thématisée (Zénone, 1981)

But then in her later work (Zénone, 1982), she collapsed these five functions into two categories: the co-textual use and the contextual use. However, Hansen (1997) argued that these five functions were not as clearly distinct as assumed and the "homonymy" analysis is not necessary.

\subsection{Hansen}


Hansen (1997) aligned with Sperber and Wilson's cognitive approach and therefore proposed to analyze the semantics of donc in term of the notion of "mutual manifestness". From this perspective, three functions were identified:

1. To mark a conclusion or a result:

Ex 6 :

A. ...c'était d'ailleurs tout à fait la position du RPR en 1979 qui avait à ce moment-là complètement refusé une liste unique avec l'UDF

B. c'était pas une position \& tactique \&\&

A. \& ça lui a pas bien réussi \&\& d'ailleurs parce que le résultat n'a pas été très hangent mais enfin

B. non mais c'était une position encore une fois fondé sur des principes, je les ai Rappelés tout à l'heure

A. donc vous avez hange de principes

(Hansen, 1997)

2. To mark a repetition of something said earlier:

Ex 7 :

A. ...je suis allée je suis arrivée au village de Sainte-Barbe il était dix heures sans mentir c'est-à-dire la nuit tombait, en plus Kiki m'avait dit le vélo dans les dunes t'y vas pied tu peux pas rouler parce que sinon tu vas péter les pneus je lui dis bon d'accord mais moi qu'est-ce que j'ai fait je me suis dit oh la la dans les dunes désertes si j'amène mon vélo toute seule ben je dis à $\mathrm{p} /$ en plus y a des tas de mecs qui passent le long de la plage tu vois

B. ah ouais ouais

A. SEULE en plus

B. bonne ambiance

A. je me suis dit oh la la non je fais pas

B. mais Sphie

A. attends attends donc je suis arrivée au village de Sainte-Barbe... (Hansen, 1997)

3. Discursive use :

Ex 8: Dis donc ; mon vieux, t'es pas doué pour ça... (Hansen, 1997)

However, Hansen did mention that the first and second use are not mutually exclusive. In the third use, donc is considered more of a modal particle than a discourse marker, as the particle tends to be pronounced without the final $[\mathrm{k}]$.

\subsection{Vlemings}

From a pragmatic point of view, Vlemings (2003) tried to distinguish between the conjunctive inferential use and the adverbial discursive use of donc. The inferential donc, which is also called the argumentative donc, marks an inferential connection between the host utterance and the antecedent (Ferrari \& Rossari, 1994). That is to say that there is always a link to an extralinguistic situation, which is made explicit by donc. He then argues that from a pragmatic perspective, the inferential use of donc could also account for its discursive use and therefore pragmatically speaking, the distinction between the two is no longer useful. As a matter of fact, the discursive use contextually derives from its inferential use, which is the core meaning.

\subsection{Bolly \& Degand}

Bolly and Degand (2009) then made a more comprehensive classification of donc according to different linguistic levels. 
1. Syntactico-semantic function: This function corresponds to the aforementioned argumentative use. The speaker relates a cause in the first segment with a conclusion in the second segment.

Ex 9:

E1 en fait deux voitures se sont rentrées dedans et euh ils étaient inconscients donc euh nous on ne savait plus passer on était bloqué par les voitures derrière par devant il y avait l'accident on ne savait plus avancer (Bolly \& Degand, 2009)

2. Discursive function: For this function, there are three sub-types of donc: repetition marker as illustrated by Hansen (1997), participative transition marker as indicated by Schiffrin (1987) (see example 10) and conceptual structuration marker as suggested by Vincent (1993) (see example 11).

Ex 10:

L3 moi-lje trouve que/ enfin même même avant-de commencer j'aillais déjà vous demander comment vous vous appeliez quoi/ même avant-de commencerll'expérience donc euh

L1 ouais-I/mais//oui et non parce-que je veux dire comment on s'appelle/si si si ça tombe on se reverra plus-du-tout tu voisl-ou

(Bolly \& Degand, 2009)

\section{Ex 11:}

E2 [identité du convoyeur] et euh le convoyeur c'était une dame et elle était enceinte et euh elle avait vraiment le poigné complètement cassé l'os qui elle avait vraiment l'os qui ressortait quoi [réaction du père] et donc mon père comme elle est enceinte et bon c'est encore plus plus dangereux donc mon père l'a pris l'a mis sur le côté

(Bolly \& Degand, 2009)

As participative transition marker, donc fulfils an interactive function, which indicates a potential speech turn changing. As conceptual structuration marker, donc establishes, by dividing the speech into segments, the referential connection between the constituent elements of this speech and insures its coherence.

3. Function as discourse punctuation :

Ex 12 :

L0 en fait euh/ je vais vous demander euh/ce que vous pensez/vraiment euh/ de la suppression des vingt-quatre heures vélo euh/ euh cette année/ si vous avez un avis làdessus/ si vous pensez euh qu'i-y-a vraim/ enfin et tout ce qui est euh/ débordements euh/ soi-disant de la vie estudiantine/ est-ce-qu'i-y-a lieu de parler de ça/ ou est-ce que/ ce que vous vous en pensez// donc voilà

(Bolly \& Degand, 2009)

\subsection{Dostie}

Dostie (2014) distinguished six functions of donc: introduce a consequence, indicate a refocusing toward the principal theme, introduce an earlier stated comment, solicit the following, suspensive donc and indicate a continuum in a narration. This classification seems to be less confusing than the others in that it does not try to define the discursive use and distinguish it from other uses while the other uses may have some overlaps with the discursive use.

\subsection{Delgar-Farrés}

Delgar-Farrés (2016) then argued that there are three main types of donc: argumentative donc (donc argumentatif), resume marker (marqueur de reprise) and discursive donc (donc discursif). The problem with this classification is the confusion created by the difference 
between what is called "marqueur de reprise" and "donc discursif". It seems that in some occasions the former one could collapse into the latter and these two are not really mutually exclusive.

For the current work, we then propose the simple distinction between the argumentative donc and the discursive donc. The argumentative donc refers to the conjunctive donc in its core meaning, which relates the consequence or result to the cause; while the discursive donc refers more to an adverbial donc with a broadened meaning.

\section{Methodology}

\subsection{Corpus and data}

The datasets that we used in the current study were extracted from the oral interaction corpus of semi-guided conversations in French carried out with 40 L2 speakers of French in France between the year of 2014 and 2017 counting a total of 30 hours of recording.

The length of each interview varies 30 minutes to 1 hour 30 minutes. A list of questions was prepared before the interview. However, these questions were used merely as a support so that the interviewee could freely talk about his experience. All interviews were recorded and transcribed entirely. Since the speakers in our corpus are all non-native speakers of French, there might be some grammatical errors in their oral production. For the transcription, these errors were not corrected. All interviews were transcribed as produced.

For this study, we did not differentiate donc and its shorterned form don. Both forms were transcribed as donc. All instances of donc in our corpus have been identified and analyzed.

\subsection{Participants}

The 40 participants are all L2 speakers of French immigrated from China to France despite their current nationality and resided in France at the time of the interview. They are not language learners but the actual language users in the target community. These speakers were recruited by the interviewer and interviewee's personal social network.

The speakers, including 22 women and 18 men, are aged between 20 and 50 years old. The time span that they spent in the community differs significantly, varying from 1 year to 13 years. Accordingly, their linguistic competence also varies. Their professions vary as well: some of them are merchants in the community while others may be students or free lancers or white collars in different French companies. They all took compulsory 500 hours' French training courses as required before coming or upon arriving in France. Their participation in our interviews is completely voluntary.

\subsection{Discursive functions of donc in non-native speech}

For the discursive functions, we will examine to what percentage donc is used as argumentative donc and discursive donc, two general categories that we proposed earlier in this article.

After a first data cleaning, we found that donc seems to have some discursive functions that were not reported in native speech, such as exemplification. We will then in the results section present with concrete examples and discuss if this is truly a new function in nonnative speech.

The third question we would like to address in this section is the difference between donc voilà and voilà donc, as we found a lot of occurrences of both combinations. 


\subsection{Extralinguistic factors}

As mentioned earlier in this article, extralinguistic factors are proven to be statistically significant to some social variants. In this study, six extralinguistic factors relevant to nonnative speech were examined to see how the social factors influence the use of donc if any and to what extent. For the significance, we will look at the P-value from the statistical point of view as well as the occurrences per person in each group for each factor over the thirty hours' recording to see the general tendency.

Firstly, we wanted to see if both genders use donc in the same way and if this discourse marker is genderly marked.

Secondly, the age factor is to be examined. The participants are divided into two different groups according to their age: $20-30$ and over 30 . As proposed by many other researchers that younger generation is more innovative in language variation, we wanted to see if the younger group would use donc more than the older group and if donc is agegraded.

Thirdly, we also examined the educational background. We have three different groups for this factor: those who only finished their undergraduate studies, those who have earned their master's degree and those who finished their $\mathrm{PhD}$ degree. We expect to see if speakers with different educational background would use donc at different frequency or if donc is preferred by speakers with certain educational background.

Fourthly, we also examined the social status. Some participants are still university students while others may have worked for some time. This difference in their social status would provide them with different contact with various groups of native speakers in varied situations where different registers are employed. We divided our participants into two groups: professionals and students. Students may have access to a more formal register as they spend more time in the academic environment, while the professionals may have access to a less formal register through their work and social activities. Since the discourse markers appear more in the informal register, we hypothesize that the professionals would use them more than the students' group.

Fifthly, as all acquisition, the mastery of discourse marker demands a certain time spent in the target community. The length of stay seems to be a relevant factor. We divided our participants into three groups according to their sojourn time in France: 1-3 years, 4-6 years and more than 7 years ( 7 years included). We suppose that the longer one stays in the target country, the more possible that one would use more donc.

At last, as discourse markers are not taught explicitly in language classroom settings, its acquisition could only be fulfilled by extracurricular contact with native speakers of French. Therefore, extracurricular contact could be an influential factor. The participants are divided into three groups depending on their self-reported contact frequency with native speakers: frequent, occasional and rare. Our hypothesis for this factor is that the more frequent this contact is, the more one would use donc.

\section{Results}

Before presenting the statistical results for different extralinguistic factors, we will first look at the general tendency of the use of donc in our corpus.

\subsection{General Tendency}

Over the 30 hours' recording, 1245 occurrences of donc were identified. Supposing one talks 24 hours a day and seven days a week continuously, the frequency of donc in our corpus would then be 1 occurrence every 1 minute 23 seconds. According to our calculation, donc is the third most frequent discourse marker in our corpus. Compared to its 
frequency in native speech, which is 1 occurrence every 55 seconds, non-native speakers use it less frequently.

\subsection{Discursive functions of donc in non-native speech}

As shown in Table 1, in our corpus, $65.30 \%$ donc were used as argumentative particle while $34.7 \%$ as discourse marker. We could clearly see from this ratio that around two thirds of donc were still used in its core meaning, which relates a conclusion or result to a cause. Compared to the native pattern, which is $54 \%$ argumentative donc and $46 \%$ discursive donc (Delgar-Farrés, 2016), the non-native speakers seem to use donc less frequently as discourse marker. However, we do can see that the non-native speakers, at least in our case, do master the discursive use of donc.

Table 1. Distribution of discursive functions of donc

\begin{tabular}{|c|c|c|c|c|}
\hline Total & $\begin{array}{c}\text { Argumentati } \\
\text { ve use }\end{array}$ & $\%$ & $\begin{array}{c}\text { Discursive } \\
\text { use }\end{array}$ & $\%$ \\
\hline 1245 & 813 & 65.30 & 432 & 34.70 \\
\hline
\end{tabular}

\subsubsection{Donc : exemplification marker?}

To our knowledge, in the native speech, donc has not been reported to be used as an exemplification marker. However, donc in example 13 seems to introduce some examples to the prior statement.

Ex 13:

Wang: donc on a trois ans d'études en Chine et un an en France et les professeurs français ils viennent en Chine pour nous donner des cours pour nous apprendre et après tout ça c'est le cursus de licence et donc la dernière année je suis allée en France et fini ma licence je continuera ma master euh c'est encore à Lille II donc après euh ensuite à Lille on a trois choix donc c'est comptabilité banque finance et aussi contrôle de gestion donc je chois banque et finance ensuite continue en M2 euh il y a aussi analyse financière et trésorerie donc j' ai choisi analyse financière

(WYT-F-2015)

As we can see here, in S1 "à Lille on a trois choix", the speaker mentioned that for her graduate study, there were three possible options as major. In S2 "c'est comptabilité banque finance et aussi contrôle de gestion", she specified what these three options are. S1 and S2 are not in cause-consequence/result relation as in argumentative use. S1 is not what causes $\mathrm{S} 2$. This donc could not be in any of the functions that were the previously illustrated. It signals neither a turn-changing nor a punctuation to the segment. S2 simply provides examples to specify what was said in $\mathrm{S} 1$.

There are two possible explanations. First, it could be a transfer from Chinese. Since the speakers in our study are all Chinese L1 speakers, it could be the equivalent of suoyi in Chinese, which has the exemplification function in oral Chinese. To the present, without any oral data to substantiate our hypothesis, we could not be sure if this is really the case. However, we do doubt its probability, since if it is due to the L1 transfer, we would then obtain much more occurrences of donc with this function. Over 30 hours' recording and among 1245 occurrences of donc identified in our corpus, only one of them was observed to have the function of exemplification. Then it leaves us to the second hypothesis: this might be a new discursive function of donc. But in order to corroborate this hypothesis, we 
would need more data from native speakers of French. For now, this only stays as a supposition.

\subsubsection{Voilà donc VS donc voilà ?}

As we know, donc could be used in association with some other discourse markers in native speakers' speech. In our corpus we found many occurrences of voilà donc and donc voilà. The question here is what is the difference between these two associations?

As shown in examples 14-16, the position of voilà donc in a sentence is relatively flexible. It could appear in utterance initial position as in the example 14, intra-utterance position as in the example 15 and sentence final position. Meanwhile, as shown in examples 17-19, donc voilà could appear in all three positions as voilà donc.

Ex 14:

Ji : c'est un choix quoi ben si on regarde l'histoire que c'est-à-dire que les hommes euh chez nous et dans le monde occidental aussi pareil que c'est-à-dire que c'est toujours une femme qui épousait ou cherchait à épouser un homme puissant et riche

Interviewer : uh huh

$\mathrm{Ji}$ : et voilà donc c'est partout pareil et maintenant que surtout le travail demande de plus en plus d'intelligence donc moins de de de comment dire de fin moins de physique quoi physiquement ça demande moins et euh donc quand tu regardes le nombre d'étudiants à l'université y a plus de femmes que les hommes

(JWH-H-2015)

\section{Ex 15:}

Zhu : et deuxièmement pardon deuxièmement en classe en 2012 y avait pas mal de profs qui qui critiquent sur certains sujets euh certains sujets un peu ambigüs un peu sérieux qui est passé en Chine

Interviewer : uh huh

Zhu : et euh après euh tout le monde commence à critiquer et voilà donc la situation l'ambiance j'ai pas très bien aimée mais même même par exemple s'ils parlaient des s'ils parlent des sujets politiques et ils ont bien raison mais euh j'ai l'impression que le prof veulent voulait orienter le sujet sur certaine direction

(ZDZ-F-2015)

\section{Ex 16:}

Liu : j'ai déjà vécu 11 ans en France donc j'ai bien adapté euh à euh ici à en tous les traditions françaises que je trouve que pendant je suis quelqu'un qui a porté deux cultures comprends deux cultures qui comprend deux euh deux pays et les gens de différents pays voilà donc

(LN-H-2014)

\section{Ex 17:}

Fang : alors là pour l'université j' arrivé um en 2013 mais avant cela j'ai fait un échange en en Bretagne au lycée j'ai été sélectionné par euh un organisme de d'échange international s'appelle AFS américan field service qui propose euh plus de cent destinations dans le monde entier

Interviewer : uh huh

Fang : donc voilà grâce à cette occasion j'ai pu j'ai pu découvrir un peu lycée français j'ai été accueilli par une une famille d'accueil française qui était vraiment sympa

(FSJ-H-2015)

Ex 18: 
Zhu : donc on a euh hmmm on a une région industrielle

Interviewer : uh huh

Zhu : qui concen $/ \mathrm{hmmm}$ beaucoup de talents travaillent là-bas et c'est plutôt en banlieue donc voilà si ah y a aussi une université

(ZDZ-F-2015)

Ex 19:

Yang : pour retravailler soit on crée quelque chose moi j'ai quelques plannings mais c'est pas mûr

Interviewer : uh huh

Yang : donc pas mûr ben c'est un peu tard mais c'est la vie comment on fait ben franchement une dame je peux dire mon âge j'ai cinquante et un an

Interviewer : uh huh

Yang : donc n'importe quel patron ne veut pas me recruter donc voilà

(YW-F-2015)

When appearing at the head of the utterance, both forms solicit the following of the utterance, where S2 justifies S1, as in the example 14 and example 17. In intra-phrasal position, as in the example 15 and 18 , both forms indicate a reformulation. In example 15, the speaker hesitates between the word "la situation" and "l'ambiance", while in example 18 , between the places, "banlieue" and "université". In both examples, the attempt to find a more exact expression could easily be identified. But then, when compared the example 16 and the example 19, where donc voilà and voilà donc are both used in the sentence final position, we could see the difference in their use. The final voilà donc in the example 16 indicates a turn-changing, while donc voilà in the example 19 was used simply as a sentence punctuation.

To sum up, the final donc voilà and voilà donc do have some different discursive functions in non-native speech, while used in other positions their functions do not differ too much. It would then be interesting to examine if the same is true for native speakers of French.

\subsection{Extralinguistic factors}

\subsubsection{Sex}

As shown in table 2, there are 22 female speakers against 18 male speakers. Over 30 hours' recording, 753 occurrences of donc were produced by women while 492 occurrences by men. Due to the uneven number of the speakers in both groups, we divided the total occurrences in each group by the number of speakers in that group to have an average estimation of the occurrences produced by each speaker in that group. The result indicated that 34.23 occurrences were produced per woman and 27.33 per man.

Table 2. Distribution of donc in two sex groups

\begin{tabular}{|c|c|c|c|c|}
\hline & $\begin{array}{c}\text { Number of } \\
\text { speakers }\end{array}$ & Occurrences & $\begin{array}{c}\text { Occurrences/ } \\
\text { Person }\end{array}$ & \\
\hline F & 22 & 753 & 34.23 & \multirow{2}{*}{$\mathrm{P}=0.37828$} \\
\cline { 1 - 4 } M & 18 & 492 & 27.33 & \\
\hline
\end{tabular}


We could see that female speakers tend to use donc somehow a little bit more frequently than male speakers. However, the statistics indicate that the sex factor is not statistically significant to the use of donc with a $\mathrm{P}>0.05$. That is to say that the discourse marker donc is not a genderly marked discourse marker.

\subsubsection{Age}

For the age groups, we have 27 speakers aged between 20 to 30 years old and 13 speakers over 30 years old. For the 20-30 age group, a total of 957 occurrences of donc were produced, which is 35.44 occurrences per person; for over 30 age group, a total of 288 occurrences of donc were identified and, which is 22.15 occurrences per person.

Table 3. Distribution of donc in two age groups

\begin{tabular}{|c|c|c|c|c|}
\hline & $\begin{array}{c}\text { Number of } \\
\text { speakers }\end{array}$ & Occurrences & $\begin{array}{c}\text { Occurrences/ } \\
\text { Person }\end{array}$ & \\
\hline $20-30$ & 27 & 957 & 35.44 & \multirow{2}{*}{$\mathrm{P}=0.05592$} \\
\hline $30+$ & 13 & 288 & 22.15 & \\
\hline
\end{tabular}

It could be told that the younger group used donc more frequently than the older group. Nevertheless, a P value at 0.05592 , even though slightly over the 0.05 threshold, proves that the age factor is not statistically significant to the use of donc.

\subsubsection{Education background}

For our speakers we have three education groups: those with bachelor's degree, those with master's degree and those with doctoral degree. The number of speakers in each group is 17,19 and 4 respectively.

Table 4. Distribution of donc in three educational groups

\begin{tabular}{|c|c|c|c|c|}
\hline & $\begin{array}{c}\text { Number of } \\
\text { speakers }\end{array}$ & Occurrences & $\begin{array}{c}\text { Occurrences/ } \\
\text { Person }\end{array}$ & \\
\hline BA & 17 & 364 & 21.41 & \multirow{2}{*}{$\mathrm{P}=0.327367$} \\
\cline { 1 - 4 } $\mathrm{MA} / \mathrm{MS}$ & 19 & 721 & 37.95 & \\
\cline { 1 - 4 } $\mathrm{PhD/MD}$ & 4 & 160 & 40 & \\
\hline
\end{tabular}

Based on the results shown in table 4, we could see that the higher the speaker's degree is, the more one tends to use more donc. However, the statistics reveal that this factor is not statistically significant to the use of donc. Unfortunately, we did not have any speaker whose education background is lower than BA. It would be interesting to see in the future with more concrete data if speakers with lower educational background use more or less donc. 


\subsubsection{Professional status}

For the professional status, we divided the speakers into two main groups: students and professionals.

Table 5. Distribution of donc in two profession groups

\begin{tabular}{|c|c|c|c|c|}
\hline & $\begin{array}{c}\text { Number of } \\
\text { speakers }\end{array}$ & Occurrences & $\begin{array}{c}\text { Occurrences/ } \\
\text { Person }\end{array}$ & \\
\hline students & 22 & 698 & 31.73 & \multirow{2}{*}{$\mathrm{P}=0.48803$} \\
\cline { 1 - 3 } $\begin{array}{c}\text { professional } \\
\mathrm{s}\end{array}$ & 18 & 547 & 30.39 & \\
\hline
\end{tabular}

Despite our hypothesis that the professionals may use donc more often than the students, table 5 shows that the professional status does not influence the use of donc with 31.73 occurrences per person for students' group and 30.39 occurrences per person for professional group. The statistics also indicates that this factor is not statistically significant with a $P$ value of 0.48803 .

\subsubsection{Length of stay}

Based on their length of stay in France, the speakers are divided into three groups: 1-3 years, 4-6 years and over 7 years.

Table 6. Distribution of donc in three length of stay groups

\begin{tabular}{|c|c|c|c|c|}
\hline & $\begin{array}{c}\text { Number of } \\
\text { speakers }\end{array}$ & Occurrences & $\begin{array}{c}\text { Occurrences/ } \\
\text { Person }\end{array}$ & \\
\hline $1-3$ years & 17 & 442 & 261 & \multirow{2}{*}{$\mathrm{P}=0.44775$} \\
\cline { 1 - 4 } $4-6$ years & 11 & 469 & 42.64 & \\
\cline { 1 - 3 } 7 years + & 12 & 334 & 27.83 & \\
\hline
\end{tabular}

The statistics reveal that this factor is not statistically significant to the use of donc with a $\mathrm{P}$ value of 0.44775 . Our hypothesis that the longer one stays in the target community one would use more donc is therefore rejected. However, what is interesting in table 6 is that among these three groups, those who have spent between 4 to 6 years in France is the group who use the most donc. This might be interpreted as an overgeneralization of the discourse marker donc in their oral production. After a certain time spent in the target community, they may have noticed the non-standard discursive use of donc in native speech. An overgeneralization may be the consequence of trying to mimic the native pattern. Then, when they have spent more than 6 years, their use pattern may truly approach the native pattern. Therefore, the frequency of the use drops in the last group.

If all these factors are not statistically significant to the use of donc in the speech of non-native speakers, then what is? The last factor we are going to test is the extracurricular contact with the native speakers. 


\subsubsection{Extracurricular contact}

Amongst 40 speakers in our study, 17 speakers reported that they have frequent contact with native speakers, 7 speakers occasional contact and 16 seldom contact with native speakers.

Table 7. Distribution of donc in three extracurricular contact groups

\begin{tabular}{|c|c|c|c|c|}
\hline & $\begin{array}{c}\text { Number of } \\
\text { speakers }\end{array}$ & Occurrences & $\begin{array}{c}\text { Occurrences/ } \\
\text { Person }\end{array}$ & \\
\hline frequent & 17 & 773 & 45.47 & \multirow{2}{*}{$* \mathbf{P}=\mathbf{0 . 0 3 9 8 4 7}$} \\
\hline occasional & 7 & 231 & 33 & \\
\hline rare & 16 & 241 & 15.06 & \\
\hline
\end{tabular}

Table 7 shows that the more frequent the extracurricular contact with the native speakers, the more one would use donc. We notice that even with occasional contact, the occurrences per person is doubled. The statistics also proves that this factor is statistically significant to the use of donc with a $\mathrm{P}$ value of 0.039847 . A post hoc test reveals that the significant difference is between those with frequent contact and those with rare contact. This means that a more frequent contact with native speakers does facilitate the mastery of the discourse maker donc.

\section{Conclusion}

As shown in the preceding, different scholars tried to distinguish the discursive functions of donc in French native speakers' speech. From different points of views, several classifications were presented. The problem that we found with these classifications is that very often the different sub-types of $d o n c$ are not mutually exclusive and therefore makes it very hard to classify. After a review of the previous work done on this subject, we proposed to distinguish only two main types of donc: the argumentative conjunctive donc, which holds its core meaning and the discursive adverbial donc, which is the donc with broadened meaning.

The current article exploits the discursive functions of donc in non-native speech as well as how extralinguistic factors influence the use of donc. After having examined 1245 occurrences of donc in our oral corpus of non-native speakers of French, we have drawn several interesting assumptions. First, we found that in our corpus, donc seems to have the exemplification function which was not found in native speech. We interpreted this either as a transfer from L1 or a new discursive function to the discourse marker donc. Second, a lot of occurrences of the association of voilà donc and donc voilà were identified. We found both combinations could appear at the initial, intraphrasal and final position. However, the final voilà donc indicates a turn-changing while the final donc voilà functions more like the sentence punctuation. Third, six extralinguistic factors that we believed would be relevant to the use of donc in non-native speech were examined but only the extracurricular contact with native speakers of French was proved to be statistically significant to donc.

Finally, for the future work, it would be helpful with more recent oral data to examine if in native speech, donc could also have the exemplification function as shown in this article. Meanwhile, it would be beneficial to verify how do native speakers use donc voilà and 
voilà donc in that whether they use both combinations. Furthermore, it would be interesting to see the association of different discourse markers in both native and non-native speech. As suggested in this article, it seems that the L2 users seem to overgeneralize donc over a certain period of time. We then would ask the question if this remains true for all types of discourse markers? To be put into a L2 language classroom setting, how can we help the students in language practice to reduce the problem of overgeneralization of certain nativelike forms? If this seems to be a mission impossible, then how do we better prepare the L2 students for the possible stigmatization of certain forms?

\section{Références bibliographiques}

Bloch, O., \& Wartburg, W. V. W. von (1968): Dictionnaire Etymologique de la Langue Francaise. Press. Univ. de France. Paris.

Bolly, C., \& Degand, L. (2009). Quelle (s) fonction (s) pour donc en français oral?: Du connecteur conséquentiel au marqueur de structuration du discours. Lingvisticae Investigationes, 32(1), 1-32.

Chanet, C. (2004). Fréquence des marqueurs discursifs en français parlé: quelques problèmes de méthodologie. Recherches sur le français parlé, 18(83), 106.

Delgar-Farrés, G. (2016). Conversation authentique et dialogue théâtral : comparaison des emplois du marqueur discursif donc en co (n) texte.

Deng, D. (2017). Oui and Voilà: Analysis of two discourse markers used by Chinese-L1 speakers of French in France. Language Discourse \&Society, 5(1), 39.

Dostie, G. (2014). Les associations de marqueurs discursifs-De la cooccurrence libre à la collocation. Linguistik online, 62(5).

Ernout, A., \& Meillet, A. (1951). Dictionnaire étymologique de la langue latine. Histoire des mots.

Ferrari, A., \& Rossari, C. (1994). De donc à dunque et quindi: les connexions par raisonnement inférentiel. Cahiers de linguistique française, 15, 7-49.

Gamillscheg, E. (1957). Historische französische syntax. M. Niemeyer.

Hansen, M. B. M. (1997). Alors and donc in spoken French: A reanalysis. Journal of Pragmatics, 28(2), 153-187.

Holm, J. (1988). Pidgins and Creoles. 2 vols. Cambridge. CUP.

Rehner, K., \& Mougeon, R. (1999). Variation in the spoken French of immersion students: To ne or not to ne, that is the sociolinguistic question. Canadian Modern Language Review, 56(1), 124154.

Rehner, K., Mougeon, R., \& Nadasdi, T. (2003). The learning of sociolinguistic variation by advanced FSL learners: The case of nous versus on in immersion French. Studies in Second Language Acquisition, 25(1), 127-156.

Sankoff, G., Thibault, P., Nagy, N., Blondeau, H., Fonollosa, M. O., \& Gagnon, L. (1997). Variation in the use of discourse markers in a language contact situation. Language variation and change, 9(2), 191-217.

Schiffrin, D. (1987). Discourse markers. Cambridge: Cambridge University Press.

Vincent, D. (1993). Les ponctuants de la langue et autres mots du discours. Québec: Nuit Blanche.

Vlemings, J. (2003). The discourse use of French donc in imperative sentences. Journal of Pragmatics, 35(7), 1095-1112.

Wartburg, W. V. (1928). Französisches etymologisches Wörterbuch: eine Darstellung des galloromanischen Sprachschatzes. F. Klopp. 
Zenone, A. (1981). Marqueurs de consécution: le cas de donc. Cahiers de linguistique française, 2(1981), 113-139.

Zenone, A. (1982). La consécution sans contradiction: donc, par conséquent, alors, ainsi, aussi (I) in Concession et consécution dans le discours. Cahiers de Linguistique Française Genève, (4), 107141. 
Filename:

1245 occurrences of the particle donc in the speech of Chinese L1 speakers of French in France-Version Finale.doc

Directory:

Template: /Users/delin/Desktop Containers/UBF8T346G9.Office/User Content.localized/Templates.localized/Normal.dotm Title: This space should be left blank, except for the name of the first author. (The publisher will re-type the main title, author names and addresses. Please give this information on a separate page.)

Subject:

Author:

Houlbert

Keywords:

Comments:

Creation Date: $\quad$ 7/24/19 6:50:00 PM

Change Number: $\quad 247$

Last Saved On: $\quad$ 12/12/19 10:22:00 AM

Last Saved By: $\quad$ DENG,Delin

Total Editing Time: 282 Minutes

Last Printed On: $\quad$ 3/28/20 4:38:00 PM

As of Last Complete Printing

Number of Pages: 14

Number of Words: $\quad 6,050$

Number of Characters: 30,693 (approx.) 